\title{
Indications for Cardiopulmonary Bypass During Pregnancy and Impact on Fetal Outcomes
}

\author{
Indikationen für kardiopulmonalen Bypass in der Schwangerschaft \\ und Auswirkung auf fetale Sterblichkeit
}

Author

Affiliation

\section{S.-M. Yuan}

Department of Cardiothoracic Surgery, The First Hospital of Putian, Teaching Hospital, Fujian Medical University, Putian, Fujian Province, China

\section{Key words \\ - birth \\ - pregnancy \\ - gynecology \\ Schlüsselwörter \\ - Geburt \\ - Schwangerschaft \\ - Gynäkologie}

$\begin{array}{lr}\text { received } & 11.7 .2013 \\ \text { revised } & 29.9 .2013 \\ \text { accepted } & 1.10 .2013\end{array}$

Bibliography

DOI http://dx.doi.org/

10.1055/s-0033-1350997

Geburtsh Frauenheilk 2014; 74:

55-62 @ Georg Thieme

Verlag KG Stuttgart · New York . ISSN 0016-5751

\section{Correspondence \\ Dr. Shi-Min Yuan}

The First Hospital of Putian

Teaching Hospital

Fujian Medical University

Department of Cardiothoracic

Surgery

389 Longdejing Street

Putian 351100

China

shi_min_yuan@yahoo.com

\section{Abstract \\ $\nabla$}

Background: Cardiac operations in pregnant patients are a challenge for physicians in multidisciplinary teams due to the complexity of the condition which affects both mother and baby. Management strategies vary on a case-by-case basis. Feto-neonatal and maternal outcomes after cardiopulmonary bypass $(\mathrm{CPB})$ in pregnancy, especially long-term follow-up results, have not been sufficiently described.

Methods: This review was based on a complete literature retrieval of articles published between 1991 and April 30, 2013.

Results: Indications for CPB during pregnancy were cardiac surgery in 150 (96.8\%) patients, most of which consisted of valve replacements for mitral and/or aortic valve disorders, resuscitation due to amniotic fluid embolism, autotransfusion, and circulatory support during cesarean section to improve patient survival in $5(3.2 \%)$ patients. During $\mathrm{CPB}$, fetuses showed either a brief heart rate drop with natural recovery after surgery or, in most cases, fetal heart rate remained normal throughout the whole course of CPB. Overall feto-neonatal mortality was $18.6 \%$. In comparison with pregnant patients whose baby survived, feto-neonatal death occurred after a significantly shorter gestational period at the time of onset of cardiac symptoms, cardiac surgery/resuscitation under CPB in the whole patient setting, or cardiac surgery/resuscitation with $\mathrm{CPB}$ prior to delivery.

Conclusions: The most common surgical indications for CPB during pregnancy were cardiac surgery, followed by resuscitation for cardiopulmonary collapse. CPB was used most frequently in maternal cardiac surgery/resuscitation in the second trimester. Improved $\mathrm{CPB}$ conditions including high flow, high pressure and normothermia or mild hypothermia during pregnancy have benefited maternal and feto-neonatal outcomes. A

\section{Zusammenfassung \\ $\nabla$}

Einleitung: Herzoperationen an schwangeren Patientinnen stellen wegen der damit verbunden Komplexität, die Mutter und Kind gleichermaßen betreffen, eine Herausforderung für Chirurgen in interdisziplinären Teams dar. Die Behandlungsentscheidung hängt von der Einzelfallbewertung ab. Bislang wurden Müttersterblichkeit sowie das Überleben von Feten/Neugeborenen nach kardiopulmonalem Bypass („cardiopulmonary bypass“ (CPB) der Mutter nicht ausreichend in der Literatur beschrieben, es fehlen insbesondere Ergebnisse der Langzeit-Verlaufsbeobachtung.

Methodik: Dieser Übersichtsartikel basiert auf einer umfassenden Literaturrecherche für den Zeitraum von 1991 bis zum 30. April 2013.

Ergebnisse: Die Indikation für den Einsatz von CPB während der Schwangerschaft stellten Herzoperationen in 150 (96,8\%) Patientinnen dar. Die häufigsten Eingriffe waren Herzklappenersatzoperationen wegen Aorten- und Mitralklappeninsuffizienz, Reanimation wegen Fruchtwasserembolie, Autotransfusion sowie Kreislaufunterstützung während des Kaiserschnitts in 5 Patientinnen. Während des CPB war entweder ein kurzer Abfall der fetalen Herzfrequenz zu verzeichnen, die sich nach der Operation wieder von selbst normalisierte, oder die fetale Herzfrequenz blieb während des ganzen CPB im Normalbereich. Die Gesamtsterblichkeit von Feten und Neugeborenen betrug 18,6\%. Verglichen mit Müttern, deren Feten/Kinder überlebten, war die fetale/neugeborenen Sterblichkeit signifikant höher, wenn mütterliche Herzinsuffizienzsymptome schon im früheren Gestationsalter auftraten bzw. bei kürzerer Schwangerschaftsdauer zum Operationszeitpunkt mit CPB.

Schlussfolgerung: Die häufigsten chirurgischen Indikationen für CPB während der Schwangerschaft waren Herzoperationen, gefolgt von Reanimationen wegen kardiopulmonalem Kollaps. Die 
shorter gestational period and the use of CPB during pregnancy were closely associated with feto-neonatal mortality. It is therefore important to attempt delivery ahead of surgery/CPB or to defer surgery till late pregnancy. häufigsten Eingriffe mit $\mathrm{CPB}$ wurden während des 2. Trimesters vorgenommen. Bessere CPB-Bedingungen, darunter höhere Fließgeschwindigkeiten, höhere Blutdruckwerte und Normothermie, oder nur milde Hypothermie haben zu einer Verbesserung der mütterlichen und fetalen Ergebnisse geführt. Kurze Schwangerschaftsdauer zum Zeitpunkt des CPB war eng mit fetaler/neugeborener Sterblichkeit korreliert. Es wird empfohlen, die Entbindung vor dem Eingriff mit CPB vorzunehmen oder aber den Eingriff mit CPB auf einem möglichst späten Zeitpunkt zu verschieben.

\section{Introduction}

$\nabla$

In 1958, Dubourg et al. [1] first reported on a repair of tetralogy of Fallot under cardiopulmonary bypass (CPB) in a pregnant patient (10th week of gestation), who unfortunately had a spontaneous abortion at 6 months' gestation. Since then, cardiac surgery with CPB has increasingly been performed in pregnant patients, with premature babies more likely to survive as medical skill and experience has improved, even though fetuses remain at high risk during maternal cardiac surgery [2]. Clinical reports have shown that cardiac surgery under CPB during pregnancy is associated with a maternal mortality of around $3 \%$, similar to that of non-pregnant patients $[3,4]$. Fetal demise was more likely with urgent, high-risk cardiac surgery and maternal co-morbidities and if surgery was carried out in the early gestational period [5]. Fetal morbidity and mortality during maternal cardiac surgery were as high as 9 and 30\%, respectively [6], and fetal mortality was much higher prior to 15 weeks' gestation compared to after 15 weeks' gestation (17 vs. 2.4\%) [7]. There is evidence that profound hypothermia with total circulatory arrest could lead to even higher fetal mortality rates [8]. A comprehensive survey revealed that fetal mortality varies during different periods of gestation; fetal mortality was 29, 3 and $0 \%$, respectively, for pregnant patients who had cardiac surgery with CPB during pregnancy, immediately after delivery, or delayed until after delivery [5].

Many case reports have described their individual experiences with cardiac surgery and СРB in pregnant patients and the fetoneonatal outcomes. CPB during pregnancy has been debated in a series of publications [4,6,9-14]. However, reviews were mostly narrative, and case reports were anecdotal. Few expressed their results with sufficient statistical support. A few surveys $[2,5,7$, 15 ] have comprehensively analyzed the published materials, offering interesting information on the topic. The excellent survey by Weiss et al. [5] was of particular interest with regard to maternal outcomes after cardiac surgery during pregnancy with or without $\mathrm{CPB}$, but their consensus on feto-neonatal outcomes may warrant further examination. At all events, feto-neonatal mortality remains a problem. In order to offer optimal care to mother and fetus, the present article aims to examine the indications for CPB during pregnancy and the impact of CPB on fetal outcome by reviewing the available data.

\section{Materials and Methods \\ $\nabla$}

Relevant literature published in English between 1991 and April 30, 2013 was retrieved from MEDLINE, Highwire Press and using the Google search engine. The search terms included "pregnancy" and "cardiopulmonary bypass", "cardiac surgical proce- dures", "congenital heart defects", "heart valves" "aortic operation", "coronary artery bypass", "cardiac neoplasms", "thrombectomy", or "amniotic fluid embolism". Information from cited references helped complete the collection of literature. Using this retrieval policy, a total of 157 articles were collected. Patients who developed aortic dissection during pregnancy and had surgery with $\mathrm{CPB}$ with or without profound hypothermic circulatory arrest, and patients with onset of cardiac symptoms after delivery who were managed surgically with CPB were not included. Pregnant patients who received off-pump coronary artery bypass were excluded from this study. After these articles had been omitted, a total of 76 reports remained [16-91]. Information on each individual case was carefully abstracted from the reports and tabulated to facilitate statistical analysis. Information collected included patients' age, gestation period at the time of onset of symptoms, gestation period at the time of $\mathrm{CPB}$, duration of gestation from onset of symptoms to $\mathrm{CPB}$, indications for $\mathrm{CPB}$, types of cardiac surgery/resuscitation, СРB conditions (arterial pressure, flow rate, minimum core temperature, СРB time and cross-clamping time), mode of delivery, gestation period at delivery, fetal heart rate (FHR), prognoses and follow-up periods for mother and baby.

Measurement data and enumeration data were expressed as mean \pm standard deviation or frequencies, and compared using paired or unpaired t-test and $\mathrm{X}^{2}$ test, respectively. Two-tailed $\mathrm{p}<0.05$ was considered statistically significant.

\section{Results \\ $\nabla$}

\section{Patient information}

A total of 76 reports with 155 patients [16-91] met the retrieval policy. Patients were aged between $28.6 \pm 5.9$ (range, 17-45; median, 28) years $(n=145)$. Their pregnancy was in the $22.3 \pm 9.2$ (range, 3-41; median, 22) week of gestation ( $n=146)$, with 28 (19.2\%), 72 (49.3\%) and 46 (31.5\%) cases, respectively, in each of the three trimesters at the time of onset of cardiac symptoms. The pregnancy was in the $23.3 \pm 9.2$ (range, $3-41$; median, 24) week of gestation $(n=144)$, with $23(16.0 \%), 67(46.5 \%)$ and 54 (37.5\%), respectively, in each of the three trimesters at the time of cardiac surgery/CPB. Three (1.9\%) patients were current or previous drug abusers.

\section{Indications for CPB}

In this patient setting, 150 (96.8\%) patients had cardiac surgery: $108(69.7 \%)$ patients had cardiac surgery at $16.1 \pm 8.4$ (range, 0.024-34; median, 17) weeks of gestation prior to delivery $(\mathrm{n}=77), 34(22.7 \%)$ patients had one-stage consecutive delivery and cardiac surgery, and 10 (7.2\%) patients had cardiac surgery performed at $0.9 \pm 1.3$ (range, 0.012-3; median, 0.1 ) weeks after 
Table 1 Indications for CPB in 155 pregnant patients.

\begin{tabular}{|l|c|}
\hline Indication & $\mathbf{n}(\%)$ \\
\hline Valvular disorder & $\mathbf{5 7 ( 3 6 . 8 )}$ \\
\hline MS & $28(18.1)$ \\
\hline MR & $9(5.8)$ \\
\hline MR, MS & $2(1.3)$ \\
\hline Mitral valve disorder (pathology not stated) & $3(1.9)$ \\
\hline AS & $10(6.5)$ \\
\hline AR, MR & $2(1.3)$ \\
\hline AS, MR, MS & $1(0.7)$ \\
\hline Aortic valve disorder (pathology not stated) & $1(0.7)$ \\
\hline TR, MR post-ASD \& pulmonary stenosis repair & $1(0.7)$ \\
\hline Congenital heart defects & $19(12.3)$ \\
\hline Atrioventricular canal defect, & $1(0.7)$ \\
\hline perforated mitral valve & \\
\hline Cor triatriatum & $1(0.7)$ \\
\hline ASD & $1(0.7)$ \\
\hline AS, bicuspid aortic valve & $6(3.9)$ \\
\hline Unicuspid aortic valve & $1(0.7)$ \\
\hline ASD, AS & $1(0.7)$ \\
\hline Ebstein's anomaly, Wolff-Parkinson-White & $1(0.7)$ \\
\hline syndrome & \\
\hline Ruptured sinus of Valsalva of the right coronary cusp & $1(0.7)$ \\
\hline Tetralogy of Fallot & $2(1.3)$ \\
\hline PFO & $1(0.7)$ \\
\hline PFO, paradoxical embolism & $1(0.7)$ \\
\hline PFO, paradoxical embolism, DIC & $1(0.7)$ \\
\hline PFO, paradoxical embolism, cardiopulmonary & $1(0.7)$ \\
\hline collapse, DIC, amniotic fluid embolism & \\
\hline Prosthetic valve disorders & $29(18.7)$ \\
\hline Prosthetic valve thrombus & $14(9.0)$ \\
\hline Prosthetic AV stuck & $3(1.9)$ \\
\hline MS post-MVR & $3(1.9)$ \\
\hline Biologic prosthetic aortic valve deterioration & $2(1.3)$ \\
\hline MS, MR post-AVR+MVR & $1(0.7)$ \\
\hline Prosthetic AS & $1(0.7)$ \\
\hline LA thrombus post-AVR & $1(0.7)$ \\
\hline Prosthetic valve problem (pathology was not given) & $4(2.6)$ \\
\hline
\end{tabular}

delivery. Five (3.2\%) patients did not have cardiac surgery but required CPB during resuscitation ( Tables 1 and 2 ).

\section{Modes of CPB}

Standard CPB was established in 150 (96.8\%) patients (deep hypothermic circulatory arrest was instituted in 2 patients for 24 and 37 minutes, respectively; intraaortic balloon pump was used in 3 patients), right femoral artery-right atrium bypass in $2(1.3 \%)$ patients, right femoral vein bypass (details not given) in 1 (0.7\%) patient, extracorporeal membrane oxygenation (left femoral artery-right femoral vein bypass) with intraaortic balloon pump (in the right femoral artery) in $1(0.7 \%)$ patient, and right atrium (inflow) - main pulmonary artery (outflow) CPB in $1(0.7 \%)$ patient in whom right ventricular assist device was used for successful weaning from $\mathrm{CPB}$. The flow rate was $3.4 \pm 1.3$ (range, 1.7-6.8; median, 2.5$) \mathrm{ml} / \mathrm{kg} / \mathrm{min}(\mathrm{n}=75)$, arterial pressure was $70.7 \pm 7.1$ (range, 50-90; median, 70$) \mathrm{mmHg}(\mathrm{n}=67)$, and minimum core temperature was $32.7 \pm 3.8$ (range, 19-38.3; median,

\begin{tabular}{|c|c|}
\hline Indication & $\mathrm{n}(\%)$ \\
\hline Cardiac tumors & $14(9.0)$ \\
\hline Myxoma & $\begin{array}{l}8(5.2) \\
(6[3.9] \text { in the LA, } \\
1[0.7] \text { in the right } \\
\text { ventricle, and } 1[0.7] \\
\text { in the right atrium) }\end{array}$ \\
\hline Right atrial lipoma & $1(0.7)$ \\
\hline Right ventricular lipoma, paroxysmal tachycardias & $1(0.7)$ \\
\hline $\begin{array}{l}\text { Recurrent LA myxoma } 8 \text { years after initial myxoma } \\
\text { resection }\end{array}$ & $1(0.7)$ \\
\hline LA osteosarcoma & $1(0.7)$ \\
\hline LA sarcoma spreading to mitral leaflet and annulus & $1(0.7)$ \\
\hline $\begin{array}{l}\text { Intravenous leiomyomatosis of uterine origin with } \\
\text { extension into the pelvic veins, inferior vena cava, } \\
\text { right atrium \& right ventricle }\end{array}$ & $1(0.7)$ \\
\hline Infective endocarditis & $12(7.7)$ \\
\hline Aortic disorders & $10(6.5)$ \\
\hline Aortic aneurysm & $\begin{array}{l}8(5.2) \\
\text { (aortic root } 2[1.3 \%] \text {, } \\
\text { ascending aorta } 2 \\
{[1.3], \text { aortic arch } 2} \\
\text { [1.3\%], descending } \\
\text { aorta } 1[0.7 \%] \text {, and } \\
\text { thoracoabdominal } \\
\text { aorta } 1[0.7 \%] \text { ) }\end{array}$ \\
\hline Ascending aorta aneurysm, mitral valve prolapse & $1(0.7)$ \\
\hline Traumatic thoracic aorta rupture & $1(0.7)$ \\
\hline Pulmonary artery embolism & $5(3.2)$ \\
\hline $\begin{array}{l}\text { Amniotic fluid embolism, cardiopulmonary } \\
\text { collapse }\end{array}$ & $\begin{array}{l}\mathbf{5}(\mathbf{3 . 2}) \\
\text { (1 [0.7\%] patient } \\
\text { had presumed } \\
\text { amniotic fluid em- } \\
\text { bolism and } 1[0.7 \%] \\
\text { patient had PFO } \\
\text { as listed above) }\end{array}$ \\
\hline Coronary artery disease & $1(0.7)$ \\
\hline Annuloaortic ectasia in Marfan syndrome & $1(0.7)$ \\
\hline $\begin{array}{l}\text { Hypertrophic cardiomyopathy (HCM), systolic } \\
\text { anterior motion of the mitral valve (SAM) }\end{array}$ & $1(0.7)$ \\
\hline Synchronous autotransfusion & $1(0.7)$ \\
\hline
\end{tabular}

AR: aortic valve regurgitation; AS: aortic valve stenosis; ASD: atrial septal defect; AVR: aortic valve replacement; DIC: disseminated intravascular coagulation; LA: left atrium; MR: mitral valve regurgitation; MS: mitral valve stenosis; MVR: mitral valve replacement; PFO: patent fossa ovalis; TR: tricuspid valve regurgitation.

33) ( $n=115)$. CPB time was $89.5 \pm 50.6$ (range, $16-340$; median, $78) \min (n=113)$, and duration of cross-clamping time was $64.1 \pm 35.2$ (range, $0-170$; median, 55$) \min (n=63)$.

A total of 131 pregnant patients delivered 132 babies at $36.3 \pm 4.2$ (range, 25-42; median, 38) weeks of gestation ( $n=108)$. Two (1.5\%) babies died after delivery. In addition, 27 fetuses died at $20.1 \pm 7.3$ (range, 7-35.4; median, 22) weeks of gestation $(n=21)$ ( Table 3). Overall feto-neonatal mortality was $18.6 \%(29 / 156)$.

\section{Fetal monitoring}

Use of fetal monitoring during cardiac surgery was reported in 27 cases: there was fetal heart asystole during aortic cross-clamping in $2(7.4 \%)$ cases, limited fetal movement in 1 (3.7\%), brief FHR drop during CPB with gradual recovery after cardiac operation in 12 (44.4\%), transient FHR drop during CPB with subsequent resolution by increasing the flow rate or temperature in $2(7.4 \%)$, and normal FHR throughout the CPB course in 10 (37.0\%) cases $\left(X^{2}=25.3, p<0.0001\right)$. 
Table 2 Cardiac surgery or resuscitation with cardiopulmonary bypass.

\begin{tabular}{|c|c|}
\hline Major operation & n (\%) \\
\hline Valve surgery & $105(67.7)$ \\
\hline 1. MVR & $34(21.9)$ \\
\hline 2. Mitral valve repair & $10(6.5)$ \\
\hline 3. MVR, tricuspid valve repair & $1(0.7)$ \\
\hline 4. MVR, TVR & $1(0.7)$ \\
\hline 5. AVR & $21(13.5)$ \\
\hline 6. AVR, MVR & $4(2.6)$ \\
\hline 7. AVR, ascending aorta replacement & $4(2.6)$ \\
\hline 8. AVR, mitral valve annuloplasty & $1(0.7)$ \\
\hline 9. AVR, ruptured sinus of Valsalva repair & $1(0.7)$ \\
\hline 10. AVR, coronary artery bypass grafting & $1(0.7)$ \\
\hline 11. Composite AVR & $1(0.7)$ \\
\hline 12. TVR & $1(0.7)$ \\
\hline 13. Redo MVR & $18(11.6)$ \\
\hline 14. Redo AVR & $7(4.5)$ \\
\hline Cardiac tumor resection & $14(9.0)$ \\
\hline 15. Cardiac myxoma excision & $7(4.5)$ \\
\hline 16. Cardiac myxoma excision, MVR & $1(0.7)$ \\
\hline 17. Cardiac myxoma excision, mitral valve repair & $1(0.7)$ \\
\hline 18. Cardiac lipoma excision & $2(1.3)$ \\
\hline 19. Cardiac leiomyomatosis excision & $1(0.7)$ \\
\hline 20. Cardiac osteosarcoma excision & $1(0.7)$ \\
\hline $\begin{array}{l}\text { 21. Incomplete resection of cardiac sarcoma, MVR, } \\
\text { modified De Vega tricuspid annuloplasty }\end{array}$ & $1(0.7)$ \\
\hline Thrombectomy & $13(8.4)$ \\
\hline 22. Pulmonary artery embolectomy & $4(2.6)$ \\
\hline $\begin{array}{l}\text { 23. Pulmonary artery embolectomy \& atrial septal defect } \\
\text { repair }\end{array}$ & $1(0.7)$ \\
\hline 24. Thrombectomy of the left atrium & $1(0.7)$ \\
\hline $\begin{array}{l}\text { 25. Embolectomy (right atrium, bilateral pulmonary arteries } \\
\text { and common iliac arteries) }\end{array}$ & $1(0.7)$ \\
\hline 26. Prosthetic mitral valve debridement \& declotting & $3(1.9)$ \\
\hline 27. Prosthetic aortic valve thrombectomy & $1(0.7)$ \\
\hline 28. Prosthetic aortic valve debridement & $2(1.3)$ \\
\hline Congenital heart defect surgery & $9(5.8)$ \\
\hline 29. Patent fossa ovalis closure & $2(1.3)$ \\
\hline 30. Patent fossa ovalis closure, paradoxical embolism removal & $2(1.3)$ \\
\hline 31. Tetralogy of Fallot repair & $1(0.7)$ \\
\hline 32. Atrial septal defect closure & $1(0.7)$ \\
\hline 33. Atrial septal defect closure, MVR & $1(0.7)$ \\
\hline 34. Accessory pathway ablation, tricuspid annuloplasty & $1(0.7)$ \\
\hline 35. Cor triatriatum repair & $1(0.7)$ \\
\hline Coronary surgery & $1(0.7)$ \\
\hline $\begin{array}{l}\text { 36. Coronary artery bypass grafting } \times 2 \text {, intraaortic balloon } \\
\text { pump }\end{array}$ & $1(0.7)$ \\
\hline Other cardiac surgery & $8(5.2)$ \\
\hline 37. Aortic aneurysm repair & $5(3.2)$ \\
\hline 38. Descending aorta-innominate artery bypass & $1(0.7)$ \\
\hline 39. Extra-anatomic bypass graft & $1(0.7)$ \\
\hline 40. Septal myectomy & $1(0.7)$ \\
\hline No cardiac operation & $5(3.2)$ \\
\hline $\begin{array}{l}\text { 41. Cesarean section under cardiopulmonary bypass } \\
\text { (circulatory support during surgery to improve the } \\
\text { patient's chances of survival) }\end{array}$ & $1(0.7)$ \\
\hline $\begin{array}{l}\text { 42. Open chest cardiac massage (no evidence of pulmonary } \\
\text { artery thrombosis) }\end{array}$ & $1(0.7)$ \\
\hline 43. Placement of a right ventricular assist device & $1(0.7)$ \\
\hline $\begin{array}{l}\text { 44. Resuscitation with extracorporeal membrane } \\
\text { oxygenation, intraaortic balloon pump }\end{array}$ & $1(0.7)$ \\
\hline 45. Synchronous autotransfusion & $1(0.7)$ \\
\hline
\end{tabular}

AVR: aortic valve replacement; MVR: mitral valve replacement; TVR: tricuspid valve replacement.
Table 3 Mode of delivery and feto-neonatal outcomes.

\begin{tabular}{|l|l|}
$\begin{array}{ll}\text { Mode of delivery } \\
\text { Cesarean section }\end{array}$ & $\begin{array}{l}\mathbf{n}(\%) \\
65(41.9) \\
(1[0.7 \%] \text { was cesarean section \& hys- } \\
\text { terectomy, and } 1[0.7 \%] \text { fetus died) }\end{array}$ \\
\hline $\begin{array}{ll}30(19.4) \\
(1[0.7 \%] \text { baby died of acute } \\
\text { respiratory distress syndrome) }\end{array}$ \\
\hline Forceps delivery & $3(1.9)$ \\
\hline Induced labor & $3(1.9)$ \\
\hline Spontaneous vaginal delivery & $23(14.8)$ \\
\hline Vacuum delivery & $(2[1.3 \%]$ stillborn $)$ \\
\hline Still with normal pregnancy when & $1(0.7)$ \\
the reports were published & $5(3.2)$ \\
\hline Operative death & $7(4.5)$ \\
\hline Spontaneous abortion & $7(4.5)$ \\
\hline Stillborn & $6(3.9)$ \\
\hline Termination of pregnancy & $5(3.2)$ \\
\hline
\end{tabular}

FHR monitoring was reported in 29 cases. Brief FHR drop occurred in $17(58.6 \%)$ cases, with a drop from $140 \pm 23.2$ (range, $120-180$; median, 135) beats per minute (bpm) to $63.2 \pm 10.5$ (range, 40-80; median, 65) bpm $(\mathrm{n}=13)(\mathrm{p}<0.0001)$. FHR remained normal at $132.5 \pm 16.6$ (range, 110-135; median, 135) $\operatorname{bpm}(\mathrm{n}=4)$ during cardiac surgery in $10(34.5 \%)$ cases. Fetal heart asystole during $\mathrm{CPB}$ was noted in two $(6.9 \%)$ cases $\left(\mathrm{X}^{2}=17.5\right.$, $\mathrm{p}=0.0002$ ).

\section{Feto-neonatal outcomes}

Follow-up was $15.5 \pm 16.0$ (range, 3-54; median, 9) months $(\mathrm{n}=22)$ for the mothers and $14.7 \pm 13.3$ (range, 3-48; median, $10.5)$ months $(n=10)$ for the neonates. There were eight hospital maternal deaths out of 155 pregnant patients, resulting in an early mortality of $5.2 \%$.

Feto-neonatal outcomes were compared between two groups: one consisting of the patients whose baby survived and the other of patients whose babies/fetuses died. Gestation periods for pregnant patients with feto-neonatal death were significantly shorter at the onset of cardiac symptoms, at cardiac surgery/resuscitation with CPB in the whole patient setting, and at cardiac surgery/resuscitation under CPB performed prior to delivery compared to patients whose baby survived. A significant difference in rates of surviving and dead fetuses/babies was also noted in terms of the gestation period at the time of delivery. There was no statistically significant difference in CPB conditions, including arterial pressure, flow rate and minimum core temperature, between patients whose baby survived and those whose baby/fetus died, and there were no differences with regard to CPB times or crossclamping times ( $\bigcirc$ Table 4).

Comparisons of gestation times among the three trimesters between patients whose baby survived and those whose baby/fetus died showed significant differences. However, no differences were found between the two groups with regard to CPB times and the time of delivery ( $\bullet$ Table 5 ). 
Table 4 Comparisons between pregnant patients whose baby survived and those whose fetus/baby died (Part 1).

\begin{tabular}{|c|c|c|c|}
\hline Variable & Survived & Died & p value \\
\hline Maternal age (year) & $28.5 \pm 6.1$ & $28.8 \pm 5.4$ & 0.8088 \\
\hline Week of gestation at onset of cardiac symptoms & $23.4 \pm 9.3$ & $17.8 \pm 7.4$ & 0.0047 \\
\hline Week of gestation at cardiac surgery & $24.2 \pm 9.4$ & $19.0 \pm 7.2$ & 0.0075 \\
\hline $\begin{array}{l}\text { Week of gestation of patients who underwent cardiac surgery under CPB } \\
\text { prior to delivery }\end{array}$ & $17.0 \pm 7.7$ & $7.3 \pm 10.8$ & 0.0030 \\
\hline Time of delivery (week of gestation) & $36.5 \pm 4.1$ & $20.1 \pm 7.3$ & $<0.0001$ \\
\hline Arterial pressure $(\mathrm{mmHg})$ & $70.4 \pm 6.6$ & $73.5 \pm 11.1$ & 0.1933 \\
\hline Flow rate $(\mathrm{ml} / \mathrm{kg} / \mathrm{min})$ & $3.3 \pm 1.2$ & $3.6 \pm 1.6$ & 0.4645 \\
\hline Temperature $\left({ }^{\circ} \mathrm{C}\right)$ & $32.7 \pm 4.0$ & $33.0 \pm 3.0$ & 0.6953 \\
\hline Cardiopulmonary bypass time (min) & $84.5 \pm 45.8$ & $108.2 \pm 68.6$ & 0.0678 \\
\hline Cross-clamping time (min) & $60.6 \pm 35.1$ & $64.9 \pm 25.0$ & 0.7011 \\
\hline
\end{tabular}

Table 5 Comparisons between pregnant patients whose baby survived and those whose fetus/baby died (Part 2).

\begin{tabular}{|c|c|c|c|c|}
\hline Variable & Survived & Died & $x^{2}$ & $\mathrm{p}$ value \\
\hline \multicolumn{5}{|c|}{ Time of gestation at onset of cardiac symptoms, $n$ (\%) } \\
\hline 1st trimester & $20(69.0)$ & $9(31.0)$ & & \\
\hline 2nd trimester & $59(80.8)$ & $14(19.2)$ & 7.86 & 0.0196 \\
\hline 3rd trimester & $44(93.6)$ & $3(6.4)$ & & \\
\hline \multicolumn{5}{|c|}{ Time of gestation at cardiac surgery, $\mathbf{n}(\%)$} \\
\hline 1st trimester & $17(70.8)$ & $7(29.2)$ & & \\
\hline 2nd trimester & $52(76.5)$ & $16(23.5)$ & 9.42 & 0.0090 \\
\hline 3rd trimester & $52(94.5)$ & $3(5.5)$ & & \\
\hline \multicolumn{5}{|c|}{ Association between use of CPB and delivery, $n$ (\%) } \\
\hline CPB ahead of delivery & $94(85.5)$ & $16(14.5)$ & & \\
\hline One-stage & $27(77.1)$ & $8(22.9)$ & 1.65 & 0.4382 \\
\hline CPB post-delivery & $9(90)$ & $1(10)$ & & \\
\hline
\end{tabular}

\section{Discussion}

$\nabla$

Pregnancies prior to cardiac surgery are associated with significantly increased rates of miscarriage, preterm delivery and onset of cardiac events [92]. CPB can compromise uteroplacental perfusion and fetal development by potential adverse effects such as coagulation and blood component alterations, the release of vasoactive substances from leukocytes, complement activation, particulate and air embolism, nonpulsatile flow, hypothermia and hypotension [7].

Three main pathophysiological changes can occur in pregnant patients under CPB: uterine contraction, placental hypoperfusion and fetal hypoxia. The fetus, placenta, and mother constitute an integrated functional unit called the feto-placento-maternal unit. Alterations to maternal physiology regulate the development of the fetus and placenta through products derived from the fetoplacento-maternal unit, including microchimeric cells, placental exosomes and particulates [93].

Uteroplacental hypoperfusion and fetal hypoxia subjected to sustained uterine contractions during $\mathrm{CPB}$ are considered risk factors for fetal death. Large extracorporeal surface contact areas and prime volumes have been evidenced as potential contributors to placental dysfunction following CPB [94]. During CPB, prostaglandin synthesis may cause an early vasoactive response, and severe acidosis may trigger fetal stress response [9]. Dilution of progesterone, cooling and rewarming processes can be causative factors for uterine contractions [11]. Placental vasoconstriction may be mediated by prostaglandins and indomethacin, and steroids administration during bypass may attenuate placental vascular resistance [95]. Pulsatile perfusion may reduce uterine contractions by releasing endothelial-derived growth factors from the vascular endothelium $[48,96]$. Infusion of cold cardioplegia may induce brief fetal bradycardia, which could be reversed by increased pump flow and core temperature [25].

Bradycardia is often the first response of the fetus to hypothermia and hypoperfusion during normal FHR ranges (120-160 bpm), whereas a FHR of $70-80 \mathrm{bpm}$ represents fetal distress. During CPB, FHR usually decreases to $100-115 \mathrm{bpm}$, but this decrease may occasionally be severe, dropping to 70-80 bpm, which represents considerable fetal distress [97]. Elevating perfusion flow and increasing the maternal oxygen partial pressure to 300 $400 \mathrm{mmHg}$ can be a solution for fetal distress [10]. The bradycardia often appears at the beginning of CPB in the event of hypoxia, secondary to decreased fetal oxygenation, placental hypotension, or acid-base imbalance, and can persist for the total duration of CPB but may be reversible by increasing perfusion flow [9]. Fetal bradycardia and demise may also be attributable to the use of nonpulsatile perfusion [98]. In addition, uterine contractions are particularly common during the rewarming phase after moderate or profound hypothermia [99]. However, experimental and clinical observations revealed hypothermia cooling to as low as $25^{\circ} \mathrm{C}$ could still result in successful pregnancies [7]. Pregnant patients undergoing valve replacement may have higher fetal mortality rates. An increased severity of the valvular pathology with advanced pregnancy and longer bypass times during cardiac surgery were considered the underlying risk factors [2]. Hyperventilation and the use of adrenaline and noradrenaline should be avoided during cardiac surgery to prevent excessive vasoconstriction [100]. But in a critical case, ephedrine and phenylephrine were exceptionally used for 5 minutes after removal of the 
aortic cross-clamp to increase maternal arterial pressure and counter the FHR drop, but inotropic administration did not have a negative effect on the fetus [27].

Teratogenic effects due to drug administration during CPB can be the main concern during the first trimester of pregnancy. СРВ can be associated with a high incidence of premature labor in the third trimester, while uterine excitability and fetal malformations could be reduced during the second trimester [15]. If cardiac surgery could be delayed to allow the fetus to mature, fetal mortality would be lower. To avoid the deleterious effect of CPB on fetal outcomes, delivery can be done by cesarean section immediately prior to cardiac surgery. Alternatively, in the third trimester, delivery can be advocated before $\mathrm{CPB}$ is started to avoid fetal distress from perfusion. However, from the maternal point of view, cardiac surgery may be tolerated better during early pregnancy [5].

A short CPB time, normothermia, the maintenance of high flow rates and perfusion pressure play important roles in fetal perfusion. Therefore, a high flow $\geq 5 \mathrm{~L} / \mathrm{min}$, high pressure of $70-$ $75 \mathrm{mmHg}$, adequate hematocrit levels (25-27\%) and mild hypothermia or normothermia, at least for a brief period during $\mathrm{CPB}$, have been advocated $[2,20,99,101]$. Increasing the flow rate of CPB to 3100-3600 mL/min may significantly improve FHR. Occasionally, increasing the pump flow did not consistently improve FHR, whereas, occasionally, successful outcomes were obtained for both mother and fetus after profound hypothermic circulatory arrest [21]. However, hydrocephalus and hydrops were observed on postoperative day 2 even with nonpulsatile perfusion at a mean arterial pressure of $77-90 \mathrm{mmHg}$, a peak flow rate of $3.5-4.0 \mathrm{~L} / \mathrm{min} / \mathrm{m}^{2}$ and a core temperature of $34-35^{\circ} \mathrm{C}$ during cardiac surgery [27]. Accordingly, the reliability of nonpulsatile normothermic CPB has been questioned and whether it can meet the needs of fetoplacental circulation. Tocodynamometer monitoring appears imperative to obtain sufficient information about the uterus to intervene where necessary [98].

Cesarean section after heparinization and cannulation of the mother before the start of CPB is another alternative to improve fetal outcome [17]. If fetal distress occurs during cardiac operation under $\mathrm{CPB}$, emergent cesarean section may save the lives of both the mother and baby [102]. Delivery prior to cardiac surgery under CPB during the third trimester can be a solution. Moreover, the cesarean incision can be left unsutured to allow further exploration of the uterus for potential hemorrhage or hematoma at a later stage [9]. In such patients, blood loss could be slightly higher and additional blood product infusions may be required [96].

The present study demonstrated that mitral and/or aortic valve disorders were the most common surgical indications for CPB during pregnancy, although it has been recognized that coronary artery disease is increasingly prevalent in gynecological patients [103]. The latter, however, could be managed interventionally in most patients, avoiding the risk associated with CPB for feto-neonatal outcome. In addition to cardiac surgery, resuscitation for cardiopulmonary collapse due to amniotic fluid embolism, autotransfusion and circulatory support during cesarean section to improve patient survival were alternative indications for $\mathrm{CPB}$. CPB was most frequently instituted during maternal cardiac surgery/resuscitation in the second trimester, and there were significant differences between the three trimesters in terms of fetoneonatal survival. Other main findings of this report were the disparities in the week of gestation at the time of onset of cardiac symptoms, time of cardiac surgery/resuscitation under $\mathrm{CPB}$, and time of delivery between patients whose baby survived and those whose fetus/baby died. This showed, on the one hand, that the onset of cardiac symptoms and cardiac surgery/CPB during the early period of pregnancy can lead to higher feto-neonatal mortality rates. On the other hand, fetal demise was often associated with premature delivery. There were no intergroup differences with regard to $\mathrm{CPB}$ conditions, including high flow, high perfusion pressure, mild hypothermia or normothermia, CPB and cross-clamping times, between patients whose baby survived and those whose baby/fetus died. CPB duration and temperature did not have a significant influence on feto-neonatal outcome in this study, which was consistent with the literature [5]. Contrary to what was reported by Weiss et al. [5], the time since gestation greatly influenced feto-neonatal outcomes. Fetoneonatal death was associated with much shorter gestation periods, whether at the time of onset of cardiac symptoms, at cardiac surgery, at cardiac surgery under CPB prior to delivery, or at delivery. Feto-neonatal mortality rates successively decreased from the first through to the third trimesters. It is plausible that insufficient intrauterine development of fetuses could be a predictive risk factor for feto-neonatal morbidity and mortality. Patients who had one-stage delivery with cardiac surgery had higher feto-neonatal mortality rates than those who had CPB ahead of delivery or those who had CPB post-delivery, but the difference did not reach a statistical significance.

Although data from different studies served as a basis for statistical analysis, the main drawback of this study was the inhomogeneity of the data. Moreover, there is still not enough information from the long-term follow-up of both mother and baby after maternal cardiac surgery/resuscitation under $\mathrm{CPB}$. These could be subjects for further study.

In conclusion, valve replacement for valvular disorder was the most common indication for maternal cardiac surgery with CPB during pregnancy. Resuscitation for cardiopulmonary collapse was an alternative indication for the initiation of CPB during pregnancy. Improved CPB conditions have led to improved fetoneonatal outcomes in pregnant patients undergoing $\mathrm{CPB}$. The period of gestation and the timing of CPB during pregnancy are closely correlated with feto-neonatal mortality. Therefore, it is important to either deliver the baby prior to surgery/CPB or to defer surgery till late pregnancy.

\section{Conflict of Interest}

$\nabla$

No conflict or financial support.

\section{References}

1 Dubourg G, Broustet P, Bricaud H et al. Complete correction of a triad of Fallot, in extracorporeal circulation, in a pregnant woman. Arch Mal Coeur Vaiss 1959; 52: 1389-1391

2 Mora CT. Pregnancy and cardiopulmonary Bypass. In: Mora CT, Guyton RA, Finlayson DC, Rigatti RL, eds. Cardiopulmonary Bypass: Principles and Techniques of extracorporeal Circulation. New York: Springer; 1995: 359-375

3 Stangl V, Schad J, Gossing $G$ et al. Maternal heart disease and pregnancy outcome: a single-centre experience. Eur J Heart Fail 2008; 10: 855860

4 Pomini F, Mercogliano D, Cavalletti C et al. Cardiopulmonary bypass in pregnancy. Ann Thorac Surg 1996; 61: 259-268

5 Weiss BM, von Segesser LK, Alon E et al. Outcome of cardiovascular surgery and pregnancy: a systematic review of the period 1984-1996. Am J Obstet Gynecol 1998; 179 (6 Pt 1): 1643-1653

6 Chandrasekhar S, Cook CR, Collard CD. Cardiac surgery in the parturient. Anesth Analg 2009; 108: 777-785 
7 Chambers CE, Clark SL. Cardiac surgery during pregnancy. Clin Obstet Gynaecol 1994; 37: 316-323

8 Sakaguchi M, Kitahara $H$, Seto $T$ et al. Surgery for acute type A aortic dissection in pregnant patients with Marfan syndrome. Eur J Cardiothorac Surg 2005; 28: 280-283; discussion 283-285

9 Parry AJ, Westaby S. Cardiopulmonary bypass during pregnancy. Ann Thorac Surg 1996; 61: 1865-1869

10 Agarwal RC, Bhattacharya PK, Bhattacharya L et al. Pregnancy and cardiopulmonary bypass. Indian J Anaesth 2004; 48: 259-263

11 Patel A, Asopa S, Tang AT et al. Cardiac surgery during pregnancy. Tex Heart Inst J 2008; 35: 307-312

12 Barth jr. WH. Cardiac surgery in pregnancy. Clin Obstet Gynecol 2009; 52: 630-646

13 Franklin WJ, Gandhi M. Congenital heart disease in pregnancy. Cardiol Clin 2012; 30: 383-394

14 Pieper PG, Hoendermis ES, Drijver YN. Cardiac surgery and percutaneous intervention in pregnant women with heart disease. Neth Heart J 2012; 20: 125-128

15 Souza MHL, Elias DO. Cardiopulmonary bypass in pregnant patients. Virtual textbook of extracorporeal technology - perfusion line. Online: http://perfline.com/textbook/toc.htm; last access: 30.09.2013

16 Strickland RA, Oliver jr. WC, Chantigian RC et al. Anesthesia, cardiopulmonary bypass, and the pregnant patient. Mayo Clin Proc 1991; 66: 411-429

17 Westaby S, Parry AJ, Forfar JC. Reoperation for prosthetic valve endocarditis in the third trimester of pregnancy. Ann Thorac Surg 1992; 53: 263-265

18 Lamarra M, Azzu AA, Kulatilake EN. Cardiopulmonary bypass in the early puerperium: possible new role for aprotinin. Ann Thorac Surg 1992; 54: 361-363

19 Shah AM, Ikram S, Kulatilake EN et al. Emergency mitral valve replacement immediately following caesarean section. Eur Heart J 1992; 13: 847-849

20 Rossouw GJ, Knott-Craig CJ, Barnard PM et al. Intracardiac operation in seven pregnant women. Ann Thorac Surg 1993; 55: 1172-1174

21 Buffolo E, Palma JH, Gomes WJ et al. Successful use of deep hypothermic circulatory arrest in pregnancy. Ann Thorac Surg 1994; 58: 1532-1534

22 Goldstein I, Jakobi P, Gutterman E et al. Umbilical artery flow velocity during maternal cardiopulmonary bypass. Ann Thorac Surg 1995; 60: 1116-1118

23 Paulus DA, Layon AJ, Mayfield WR et al. Intrauterine pregnancy and aortic valve replacement. J Clin Anesth 1995; 7: 338-346

24 Sheikh F, Rangwala S, DeSimone C et al. Management of the parturient with severe aortic incompetence. J Cardiothorac Vasc Anesth 1995; 9: 575-577

25 Garry D, Leikin E, Fleisher AG et al. Acute myocardial infarction in pregnancy with subsequent medical and surgical management. Obstet Gynecol 1996; 87 (5 Pt 2): 802-804

26 Golden LP. Aortic valve repair and arch replacement during pregnancy: a case report. AANA J 1996; 64: 243-254

27 Khandelwal M, Rasanen J, Ludormirski A et al. Evaluation of fetal and uterine hemodynamics during maternal cardiopulmonary bypass. Obstet Gynecol 1996; 88 (4 Pt 2): 667-671

28 Lemermeyer G, Talwar MK, Mullen JC et al. Traumatic rupture of the thoracic aorta during the second trimester of pregnancy. Ann Thorac Surg 1996; 61: 1541-1543

29 Tzankis G, Morse DS. Cesarean section and reoperative aortic valve replacement in a 38-week parturient. J Cardiothorac Vasc Anesth 1996; 10: $516-518$

30 Nakata S, Nakano S, Mitsuda $N$ et al. Recurrent left atrial myxoma in a patient with a twin fetus pregnancy. Jpn Circ J 1996; 60: 130-132

31 Kole SD, Jain SM, Walia A et al. Cardiopulmonary bypass in pregnancy. Ann Thorac Surg 1997; 63: 915-916

32 Fleyfel M, Bourzoufi K, Huin G et al. Recombinant tissue type plasminogen activator treatment of thrombosed mitral valve prosthesis during pregnancy. Can J Anaesth 1997; 44: 735-738

33 Woodward DK, Birks RJ, Granger KA. Massive pulmonary embolism in late pregnancy. Can J Anaesth 1998; 45: 888-892

34 Zellner JL, Kribbs SB, Dorman BH et al. Cardiopulmonary bypass in a gravid patient: perioperative changes in endothelin levels. Ann Thorac Surg 1998; 66: 268-270

35 Kawkabani N, Kawas N, Baraka A et al. Case 3-1999. Severe fetal bradycardia in a pregnant woman undergoing hypothermic cardiopulmonary bypass. J Cardiothorac Vasc Anesth 1999; 13: 346-349
36 Tripp HF, Stiegel RM, Coyle JP. The use of pulsatile perfusion during aortic valve replacement in pregnancy. Ann Thorac Surg 1999; 67: 11691171

37 Ecknauer E, Schmidlin D, Jenni R et al. Emergency repair of incidentally diagnosed ascending aortic aneurysm immediately after caesarean section. Br J Anaesth 1999; 83: 343-345

38 Carnero-Alcázar M, Reguillo-Lacruz F, Montes-Villalobos $L$ et al. Mechanical prosthetic mitral valve thrombosis in a first trimester pregnant woman. Interact Cardiovasc Thorac Surg 2010; 10: 116-118

39 Baraka A, Kawkabani N, Haroun-Bizri S. Hemodynamic deterioration after cardiopulmonary bypass during pregnancy: resuscitation by postoperative emergency Cesarean section. J Cardiothorac Vasc Anesth 2000; 14: 314-315

40 Ling FT, David TE, Merchant $N$ et al. Intracardiac extension of intravenous leiomyomatosis in a pregnant woman: A case report and review of the literature. Can J Cardiol 2000; 16: 73-79

41 Mahli A, Izdes S, Coskun D. Cardiac operations during pregnancy: review of factors influencing fetal outcome. Ann Thorac Surg 2000; 69: 1622-1626

42 Hsieh YY, Chang CC, Li PC et al. Successful application of extracorporeal membrane oxygenation and intra-aortic balloon counterpulsation as lifesaving therapy for a patient with amniotic fluid embolism. Am J Obstet Gynecol 2000; 183: 496-497

43 Korbel' M, Kanáliková K, Fischer $V$ et al. Management of intracavitary left atrium tumors during pregnancy - two case reports. Zentralbl Gynakol 2001; 123: 590-592

44 Penning S, Thomas N, Atwal $D$ et al. Cardiopulmonary bypass support for emergency cesarean delivery in a patient with severe pulmonary hypertension. Am J Obstet Gynecol 2001; 184: 225-226

45 Salazar E, Espinola N, Molina FJ et al. Heart surgery with cardiopulmonary bypass in pregnant women. Arch Cardiol Mex 2001; 71: 20-27

46 Gopal K, Hudson IM, Ludmir J et al. Homograft aortic root replacement during pregnancy. Ann Thorac Surg 2002; 74: 243-245

47 DeLaRosa J, Sharoni E, Guyton RA. Pregnancy and valvular heart disease. Heart Surg Forum 2002; 6: E7-E9

48 Jahangiri $M$, Clark J. Surgery for type A aortic dissection in pregnant patients with Marfan syndrome. Eur J Cardiothorac Surg 2006; 29: 264; author reply 264-265

49 Schrepfer S, Deuse T, Detter C et al. Successful resection of a symptomatic right ventricular lipoma. Ann Thorac Surg 2003; 76: 1305-1307

50 Sharma JB, Nigam M, Tempe A et al. Cesarean section and reoperative mitral valve replacement for thrombosis of a mechanical valve in a 32-week parturient. Acta Obstet Gynecol Scand 2003; 82: 89-90

51 Stanten RD, Iverson LI, Daugharty TM et al. Amniotic fluid embolism causing catastrophic pulmonary vasoconstriction: diagnosis by transesophageal echocardiogram and treatment by cardiopulmonary bypass. Obstet Gynecol 2003; 102: 496-498

52 Karahan N, Oztürk T, Yetkin U et al. Managing severe heart failure in a pregnant patient undergoing cardiopulmonary bypass: case report and review of the literature. J Cardiothorac Vasc Anesth 2004; 18: 339-343

53 Tehrani H, Masroor S, Lombardi P et al. Beating heart aortic valve replacement in a pregnant patient. J Card Surg 2004; 19: 57-58

54 Funakoshi $Y$, Kato M, Kuratani T et al. Successful treatment of massive pulmonary embolism in the 38th week of pregnancy. Ann Thorac Surg 2004; 77: 694-695

55 Liuzzo JP, Shin YT, Lucariello $R$ et al. Triple valve repair for rheumatic heart disease. J Card Surg 2005; 20: 358-363

56 Sutton SW, Duncan MA, Chase VA et al. Cardiopulmonary bypass and mitral valve replacement during pregnancy. Perfusion 2005; 20: 359368

57 Willcox TW, Stone P, Milsom FP et al. Cardiopulmonary bypass in pregnancy: possible new role for the intra-aortic balloon pump.J Extra Corpor Technol 2005; 37: 189-191

58 Cho FN. Management of pregnant women with cardiac diseases at potential risk of thromboembolism - experience and review. Int J Cardiol 2009; 136: 229-232

59 Koçak H, Karapolat S, Gündogdu C et al. Primary cardiac osteosarcoma in a pregnant woman. Heart Vessels 2006; 21: 56-58

60 Neema PK, Sethuraman M, Rathod RC. Implications of intraoperative transesophageal echocardiography detection of ruptured sinus of valsalva in a patient with severe aortic regurgitation undergoing aortic valve replacement. J Cardiothorac Vasc Anesth 2006; 20: 847-849 
61 Witters I, Cannie M, Moerman P et al. Fetal caudal dysgenesis after maternal cardiopulmonary bypass in pregnancy. Ultrasound 2007; 15 : $71-72$

62 Fayad G, Larrue B, Modine T et al. Extracorporeal membrane oxygenation in severe acute respiratory failure in postpartum woman with rheumatic mitral valve disease: benefit, factors furthering the success of this procedure, and review of the literature. J Extra Corpor Technol 2007; 39: 112-116

63 Shastri C, Kane D, Shroff PP et al. Cardiopulmonary bypass in pregnancy: an experience of three different clinical scenarios. Internet J Anesthesiol 2007; DOI: 10.5580/2136

64 Lin TY, Chiu KM, Shieh JS et al. Emergency redo mitral valve replacement in a pregnant woman at third trimester: case report and literature review. Circ J 2008; 72: 1715-1717

65 Taniguchi S, Fukuda I, Minakawa M et al. Emergency pulmonary embolectomy during the second trimester of pregnancy: report of a case. Surg Today 2008; 38: 59-61

66 Nagarsheth NP, Pinney S, Bassily-Marcus A et al. Successful placement of a right ventricular assist device for treatment of a presumed amniotic fluid embolism. Anesth Analg 2008; 107: 962-964

67 Vincelj J, Sokol I, Pevec D et al. Infective endocarditis of aortic valve during pregnancy: a case report. Int J Cardiol 2008; 126: e10-e12

68 Hatfield T, Kraus H, McConnell D et al. Synchronous autotransfusion during cesarean hysterectomy. Am J Obstet Gynecol 2010; 202: e15e16

69 Marcoux J, Rosin M, Mycyk T. CPB-assisted aortic valve replacement in a pregnant 27-year-old with endocarditis. Perfusion 2009; 24: 361-364

70 Sindjelic R, Vlajkovic G, Djukic P. Management of right ventricular myxoma diagnosed at full-term pregnancy. Med Sci Monit 2009; 15: CS158-CS161

71 Bai W, Kaushal S, Malviya S et al. Anesthetic management for resection of cor triatriatum during the second trimester of pregnancy. Int J Obstet Anesth 2010; 19: 103-106

72 Hajj-Chahine J, Jayle C, Tomasi J et al. eComment. Left tilt position for cardiopulmonary bypass in parturient patients. Interact Cardiovasc Thorac Surg 2012; 15: 287

73 Kumar S, Wong G, Maysky $M$ et al. Amniotic fluid embolism complicated by paradoxical embolism and disseminated intravascular coagulation. Am J Crit Care 2010; 19: 379-382

74 Muretti M, Torre TM, Mauri R et al. Mitral valve replacement in pregnancy: a successful strategy for fetal survival. J Heart Valve Dis 2010; 19: 789-791

75 Price JW, Klas M. Emergency tricuspid valve replacement during pregnancy. J Clin Anesth 2010; 22: 454-459

76 Lee PH, Shulman MS, Vellayappan $U$ et al. Surgical treatment of an amniotic fluid embolism with cardiopulmonary collapse. Ann Thorac Surg 2010; 90: 1694-1696

77 Datt V, Tempe DK, Virmani S et al. Anesthetic management for emergency cesarean section and aortic valve replacement in a parturient with severe bicuspid aortic valve stenosis and congestive heart failure. Ann Card Anaesth 2010; 13: 64-68

78 Jafferani A, Malik A, Khawaja RD et al. Surgical management of valvular heart diseases in pregnancy. Eur J Obstet Gynecol Reprod Biol 2011; 159: $91-94$

79 John AS, Connolly HM, Schaff HV et al. Management of cardiac myxoma during pregnancy: a case series and review of the literature. Int J Cardiol 2012; 155: 177-180

80 Firstenberg MS, Abel E, Blais D et al. Temporary extracorporeal circulatory support and pulmonary embolectomy for catastrophic amniotic fluid embolism. Heart Surg Forum 2011; 14: E157-E159

81 Kochhar PK, Zutshi V, Shamsunder S et al. Emergency aortic valve replacement and Caesarian section in a primigravida with severe aortic stenosis: a case report. Heart Asia 2011; 3: 72-76
82 Frank S, Pochmalicki G, Achor A et al. Successful resection of an intracardiac lipoma during the first trimester of pregnancy, coming to term normally. Eur J Obstet Gynecol Reprod Biol 2012; 160: 236-237

83 Sato S, Ogino H, Matsuda $\mathrm{H}$ et al. Annuloaortic ectasia treated successfully in a pregnant woman with Marfan syndrome: report of a case. Surg Today 2012; 42: 285-287

84 Bliacheriene F, Avila WS, Bortolotto MR et al. Anesthesia for cardiac surgery under cardiopulmonary bypass in pregnant patients: experience with nine cases. Int J Obstet Anesth 2012; 21: 388-389

85 Kither HJ, Stephen G, Vause S. Atrial myxoma in early pregnancy. Arch Dis Child Fetal Neonatal Ed 2012; 97: A52

86 Gaitan B, Cooper L, Craner R et al. Successful management of cardiopulmonary bypass during first trimester of pregnancy. Online: http://www2.scahq.org/sca3/events/2013/annual/posters/ann-uploads/249-SCA-160; last access: 30.09.2013

87 Reyes OLE, Muñoz L, Maldonado CE. Pulmonary embolectomy and cardiopulmonary bypass during pregnancy. Rev Colomb Anestesiol 2013; 41: 166-170

88 Mokgwathi GT, Lebakeng EM, Ogunbanjo GA. Positive maternal and foetal outcomes after cardiopulmonary bypass surgery in a parturient with severe mitral valve disease. South Afr J Anaesth Analg 2011; 17: 299-302

89 amsect.societyhq.com/meetings/international/.../FRI\%20Benson\% 201530.pdf; last access: 30.09 .2013

90 Mahoori A, Farasatkish R, Aghdaie $N$ et al. Outcome of anesthesia and open heart surgery in pregnant patients. J Teh Univ Heart Ctr 2007; 2: 21-24

91 Cinar S, Doganci S, Yildirim Vet al. From recussitation to birth: double valve replacement due to infective endocarditis in pregnant woman. J Clin Anal Med 2012; 3: 88-91

92 Actis Dato GM, Rinaudo P, Revelli A et al. Atrial septal defect and pregnancy: a retrospective analysis of obstetrical outcome before and after surgical correction. Minerva Cardioangiol 1998; 46: 63-68

93 Clifton VL, Stark MJ, Osei-Kumah A et al. Review: The feto-placental unit, pregnancy pathology and impact on long term maternal health. Placenta 2012; 33 (Suppl.): S37-S41

94 Lombardi J, Sedgwick J, Schenbeck J et al. Cardiopulmonary bypass in the immature fetus through novel use of a mini-centrifugal pump. Perfusion 2006; 21: 185-191

95 Sabik JF, Heinemann MK, Assad RS et al. High-dose steroids prevent placental dysfunction after fetal cardiac bypass. J Thorac Cardiovasc Surg 1994; 107: 116-125

96 John AS, Gurley F, Schaff HV et al. Cardiopulmonary bypass during pregnancy. Ann Thorac Surg 2011; 91: 1191-1196

97 Souza MHL, Elias DO. Guidelines for cardiopulmonary bypass during pregnancy. Online: http://perfline.com/guidelines/pregnancy.shtml; last access: 30.09 .2013

98 Jahangiri $M$, Clarke J, Prefumo $F$ et al. Cardiac surgery during pregnancy: pulsatile or nonpulsatile perfusion? J Thorac Cardiovasc Surg 2003; 126: 894-895; erratum in: J Thorac Cardiovasc Surg 2003; 126 : 1680

99 Becker RM. Intracardiac surgery in pregnant women. Ann Thorac Surg 1983; 36: 453-458

100 Iscan ZH, Mavioglu L, Vural KM et al. Cardiac surgery during pregnancy. J Heart Valve Dis 2006; 15: 686-690

101 Korsten HHM, van Zundert AAJ, Mooij PNM et al. Emergency aortic valve replacement in the 24th-week of pregnancy. Acta Anaesth Belg 1989; 40: 201-205

102 Martin MC, Pernoll ML, Boruszak AN et al. Cesarean section while on cardiac bypass: report of a case. Obstet Gynecol 1981; 57 (6 Suppl.): 41S-45S

103 Jantzen J-P, Bader $W$. The cardiac risk patient presenting for gynecological surgery. Geburtsh Frauenheilk 2011; 71: 183-186 